\title{
Early Modern Transgender Fairies
}

The fairies died out in the sixteenth century. Once a commonplace of the English landscape, creatures of the dangerous and marginal places, by the mid-seventeenth century fairies had come to be recognized as idle fancies or - for more imaginative Protestants - disguised demons. The monstrous, transgressive fairies of medieval English folklore were absorbed into the pretty, fanciful literature of William Shakespeare, Ben Jonson, Robert Herrick, and their contemporaries, from which are descended the "wee folk, good folk" (Allingham 1908: 339) of Victoriana fairy tales and modern fairies (Purkiss 2000: 158). ${ }^{1}$ The fairies of early modernity found their way out of the English wilds and onto the stage and page, where they safely remained; it is here that some of the most recognizable and lasting literary fairies were created. And the gender of these fairies was remarkably unstable. This article pursues how a range of concepts we might call "transgender" manifest in the early modern literary imagination instabilities, transformations, ambiguities, or indeterminacies in sex and gender - through the representation of fairies. I focus on three texts, two canonical and one marginal: Shakespeare's The Tempest, Edmund Spenser's The Faerie Queene, and Thomas Randolph's Amyntas. In these I discuss three main themes: Ariel and genderless children; Duessa and deceptive, non cis women; and Jocastus' promise of transsexual transformation. The article also engages throughout with how age and gender intersect in conceptualisations of early modern gender instability and how violent or phobic reactions to gender instability differ from or provide potential antecedents to modern transphobia, with especial attention to Julia Serano's interpretation of transmisogyny.

This is necessarily an article about trans historicity. ${ }^{2}$ In queer theory, the tension between ancestralism and anachronism finds a broad solution in Valerie Traub's (2002: 32) compromise, "assum[ing] neither that we will find in the past a mirror image of ourselves nor that the past is so utterly alien that we will find nothing useable in its fragmentary traces." But debate remains on how one navigates sexual desire in the past, with historicism (Bray 1982, Goldberg 1992, Smith 1995, Traub, 2002), unhistoricism (Freccero 2006, Menon 2016), homohistory (Menon 2016), and deconstructionism (Dinshaw 1999) providing alternative methodologies. ${ }^{3}$

Ancestralism seeks to construct a historical continuity of transness and is most commonly represented by archivism or shadow histories that identity people such as Eleanor Rykener as early transgender figures. Here I may borrow - and queer - a theoretical axiom from Peregrine Horden's (1999: 45) work on dragons in the dark ages: "Dragons exist. [...] Let us entertain the idea that never having seen a dragon may reflect only narrowness of experience." Let us apply this formulation to early modern fairies: for many medieval people, fairies exist. We might say the same of trans people, and having found few trans people in the archives - such as Rykener, Mary Frith ("Moll Cutpurse"), Eleno de Céspedes, Alonso Díaz (Catalina de Erauso), and, more recently Chevalier d'Éon and Juana Aguilar - may reflect only narrowness of experience. ${ }^{4}$

\footnotetext{
${ }^{1}$ For overviews of medieval fairies, see R. Green 2016 and Harf-Lancner 1984.

${ }^{2}$ See Aizura et al. 2014 and Felski 1996.

${ }^{3}$ Ari Friedlander provides a good overview of the state of this field (2016: 1-20).

${ }^{4}$ On historical trans figures in the medieval and early modern periods, see G. Wagner 2011; Goldmark 2015, E. Rose 2016, Karras and Linkinen 2016, Boon 2018, Bychowski et al. 2018, Clifton 2018.
} 
Unhistoricist trans temporalities, by contrast, are "asynchronous and nonnormative, and thus enabling of community formation" (Devun and Tortorici 2018: 520). As Leah DeVun and Zeb Tortorici point out, many scholars argue that attempts to construct histories of "transgender" are impossible "before the advent of the very vocabulary that generated its subject; to do so would risk divesting past gender practice of what made it meaningful in its own time and place" (520). ${ }^{5}$ My methodology is primarily historicist, but I employ the kinds of "touches" advocated by unhistoricists such as Carolyn Dinshaw, whom I follow in "collapsing time through affective contact between marginalized people now and then" (Dinshaw et al. 2007: 178). I follow also Simone Chess, Colby Gordon, and Will Fisher (2020) in "tak[ing] aim at the misguided supposition that transition was unthinkable until the development of hormone therapies and surgical interventions." There are those who understand the transsexual as a product of twentieth century technology - Paul Preciado (2013) is eloquent on this theme - but while the surgical realities of sex affirmation are recent, the imaginative conception of sexual transformation is an ancient idea. My interest, then, is not with ancestralism but the representation of transgender concepts in the literary imagination. For brevity, I use "transgender" as a catch-all for forms of gender instability, rather than as a term designating identity. I also follow the medievalists M. W. Bychowski and Dorothy Kim (2018: 130) who argue "Neither medieval nor transgender existed as words used by people in fourteenth century England, yet medieval and transgender describe realities that may exist regardless of whether a person whom they describe possessed the terminology" $(2019,20)$. My focus, however, is not the middle ages but the more neglected sphere of early modernity.

Early modern trans studies is still wet behind the ears. ${ }^{6}$ In contrast to the "transgender middle ages,"7 early modern trans studies is - as Chess, Gordon, and Fisher (2020) put it - "a little bit late to the party." Most research on gender instability in the early modern period has been confined to discussions of cross-dressing and boy actors, ${ }^{8}$ and only very recently has this been examined through the lens of trans theory. ${ }^{9}$ Outside of but influential to trans studies, work on early modern gender instability has engaged with the materiality of gender, or gender as prostheses. ${ }^{10}$ It is also important to note work on "boys" as a separate gender category to men, pioneered by Will Fisher (2001), as well as Traub's (2002) work on the role of phalluses in lesbian identities. The subject of the early modern supernatural and transness remains a curious lacuna among this scholarship, although some work has been done in medieval and theological

${ }^{5}$ A concept problematised in Gamble 2020.

6 Though few publications, there have been a number of conferences and seminars on early modern trans studies. See "Trans* Historicities" at SAA 2016, "Trans/Early/Modern" at MLA 2018, "Shakespeare and Transgender Theory" at 2018 SAA, and "Early Modern Trans Studies" at Bryn Mawr College (2019).

${ }^{7}$ See Bychowski 2016; Whittington 2018, Gutt 2018, Boon 2018, Mills 2018, Bychowski and Kim 2019, Gutt and Spencer Hall.

${ }^{8}$ For early modern gender instability and cross-dressing on stage, see Howard 1988; Stallybrass 1992; Levine 1994; Orgel 1996; Sedinger 1997; Jones and Stallybrass 2000; Fisher 2001; Munro 2009; Johnston 2011; Sparey 2015; Johnston 2017; Stavreva 2018; Chess 2020; Rubright 2020.

${ }^{9}$ See Pfeffer 2013; Masten 2016; Varnado 2016; Munro 2018; Kemp 2019; Chess, Colby, Fisher 2020; Klosowska, Raskolnikov, and LaFleur, 2021.

${ }^{10}$ Fisher 2006 and 2001; Johnston 2011; Jones and Stallybrass 2000; Klett 2008; Shaughnessy 2010. 
areas, ${ }^{11}$ and some on animality. ${ }^{12}$ Theoretically, I draw on queer theory, historicism, and trans temporalities, moving between the past and present to variably historicise early modern transness and to bridge continuities with modern experiences. Some topics I omit for the sake of scope, such as the intersection with race, ${ }^{13}$ with disability, with the relationship with the one-sex model, ${ }^{14}$ and the medicalized "hermaphrodite." ${ }^{15}$ Early modernity understood transgender elements as fantastic and potentially wondrous, but also employed them for comic or phobic purposes. The encounters in these texts often affirm rather than destabilize cisheteronormativity, and may present a threatened, uneasy understanding of the mutability of sex and gender. This is the period in which the legacy of medieval fairies was transformed and codified into the archetypical fairies of modern literature, with figures such as Puck, Oberon, and Mab displacing will-o-the-wisps, changelings, and green children in the popular imagination. As fairies were literarily domesticated, the popular supernatural potential for gender instability shifted.

I begin with beginnings: with childhood. Transgender children are excluded from their own histories. Gatekeepers claim they "have no history at all. Trans children are unprecedented and must be treated as such, with caution or awe" (Gill-Peterson 2018: 2). Julian Gill-Peterson challenges this narrative, identifying accounts of trans children in early twentieth century medical records, but I wish to extend this refusal of the falsified novelty of trans children to an earlier point. I do not consider "transgender children" in the same sense as Gill-Peterson, as I am dealing not with real children but their fictional representation. Indeed, as Jacqueline Rose (1984: 3) argues of Peter Pan, "Peter Pan is a little boy who does not grow up, not because he doesn't want to, but because someone else prefers that he shouldn't [...] what is at stake in Peter Pan is the adult's desire for the child"; and, furthermore, "the child can be used to hold off a panic [...] that sexuality, while it cannot be removed, will eventually take on the forms in which we prefer to recognize and acknowledge each other" (10). This use of the constructed child to stave off a premature or nonnormative sexuality is further explored by Eve Kosofky Sedgwick (1991: 19) in a sociological sphere, where revisionist analysts only like "healthy homosexual[s]" who have "already grown up." At the time of her writing, there remained an absence in the discussion of "proto-gay children" (22), and even today queer children are often only recognized retroactively, once the queer adult already exists, perceptible only by a "backward birthing mechanism" (Stockton 2009: 7). The same problem arises for trans people. The trans child is presented as a novel phenomenon that can only be understood from the retrospective selfnarrativization of the trans adult, which Spade (2006: 319-20) challenges, finding "the gay childhood narrative" "strategic" and working to reject the theory that "forecloses the possibility that anyone, gender-troubled childhood or not, could transgress sexual and gender norms at any time." In the panic over twenty first century transgender children, who are treated like The Midwich Cuckoos, what is at stake is not the real child but the Image of the child (Edelman:

${ }^{11}$ See Gutt 2018; Mills 2018; Crawford 2020; Sanchez 2020; Gutt and Spencer-Hall.

${ }^{12}$ Gordon 2020 and Dugan 2020. On early modern perceptions of animals as hermaphroditic, see DiGangi 1997: 57; Pendergraft 1992: 75-9; Long 2006: 71-6.

${ }^{13}$ For early modern trans studies and race, see S. Wagner 2020 and Arvas 2020.

${ }^{14}$ See Lacquer 1990 and King 2013.

${ }^{15}$ While such figures share structurally similar traits of monstrosity with some early modern fairies, they are nonetheless distinct and we must be wary of the "incoherent" view we develop of the early modern hermaphrodite by reading medical literature alongside the literary (Mann 2006: 68). 
2004). The idea that gender instability in children is a product of modern medical practices is a pose, a political strategy, devised not to protect children but the dominant social order. This is the frame with which I approach The Tempest's Ariel. The childlike, protean Ariel is treated not with the novelty or panic induced by the modern transgender child but with temperance and affection. While such ways of thinking about children have been erased because "trans children were central to the medicalization of sex and gender during the twentieth century in a very specific way, made valuable through a racialized discourse of plasticity" (Gill-Peterson 2018: 3), I demonstrate positive, non-phobic fantasies of "transgender children" and provide a starting point for an earlier history of childhood and gender divergence.

Ariel's childlike nature brings into question the age of fairies. Childhood may be characterized by "growing toward a question mark", or "growing sideways", as Kathryn Bond Stockton (2009: 6) writes. Early modern childhood was a genderless or feminine sphere, wherein boys and girls dressed identically (before breeching), and both were under the care of first midwives and then mothers, sisters, and nurses. In order to grow up, little boys in the early modern period moved "from the world of the household, dominated by mothers and nurses, to the public world of education, church and state, overwhelmingly dominated by men" (Purkiss 2000: 138). For boys to move between these states, from feminine childhood to masculine adulthood, they had to be educated and disciplined. A boy was made a man by a humanist education. They had to be taught Latin, Greek, and philosophy in order to rid their heads of "old wives' fairy rubbish," as Erasmus (1904: 214) describes it. Such education had to be accompanied by discipline, often by corporal punishment. A child must be beaten in order to dissuade him from feminine corruption and pedagogy, or he will never "grow up."16 A boy must be educated and disciplined in order to exorcise the fairies.

But a child who does not grow up cannot be educated or masculinized and remains growing towards Stockton's question mark. "[C]hildren grow sideways as well as up," writes Stockton (2009: 6), partly because "they cannot, according to our concepts, advance to adulthood until we say it's time." In this sense, the fairy is usefully thought of as a figure analogous to contemporary discussions of arrested development in queer culture, what Jack Halberstam (2005: 153) describes as "the stretched-out adolescences of queer culture makers that disrupt conventional accounts of subculture, youth culture, adulthood, and maturity." Like boys, fairies are often creatures of mischief. Many of Shakespeare's fairies are also subservient to a figure of nobility, and while such fairies may meet occasional discipline, this is only ever to ensure the aims of the disciplinarian are correctly carried out and it is never for the fairy's maturation. Such forms of discipline do not prevent mischief, they only ensure that the correct sort of mischief is performed. So thus we see Oberon's chastising of Puck - "What hast thou done?" (III.ii.88) and Prospero's of Ariel - "Thou liest, malignant thing!" (I.ii.257) - but this is only ever to redirect their mischief, not to curb it. School boys might fear the birch, but the oak is Prospero's punishment of choice, and it is not one easily escaped: "I will rend an oak | And peg thee in his knotty entrails" (I.ii.295). The Victorian association between fairies and childhood that gives us Peter Pan is rooted in this Shakespearean repurposing of fairies' violence as childish mischief. A mortal boy must have the fairies beaten out of him, but a fairy is never expected to grow up.

\footnotetext{
${ }^{16}$ For gender and sexuality in the corporal discipline of humanist educational practices, also see Halpern 1991, 26-8; Bushnell 1996; Stewart 1997; Enterline 2012; Horbury 2019, 1-42.
} 
Prospero's treatment of Ariel is an ambiguous pose of both father and the schoolmaster, but while the question of Ariel's gender has long provoked oblique discomfort it has received little direct critical discussion. As Christine Dymkowski (2000: 48) writes in one of the few sustained treatments of the subject, "Although [...] the English theatre has often used Ariel's gender as an instrument of ideological struggle, it has rarely used Ariel to contest the dominant cultural view of gender itself." The part of Ariel may have been played by a woman as early as the Restoration, ${ }^{17}$ and was predominantly a female role between the eighteenth and mid-twentieth centuries (Button 2001; Dymkowski 2000: 34). ${ }^{18}$ This chronology demonstrates how easily seventeenth century audiences could accept a woman as the part, ${ }^{19}$ while later performances both served to translate Ariel's mystical otherness into a kind of feminine mystique, as well as to accord with the Victorian view of fairies as tinkling fancies meant for the feminine realm of childhood. I wish to deconstruct the means by which Ariel's gender has been traditionally assembled.

Physically, Ariel is often (depending on when we identify Ariel's costume changes, ${ }^{20}$ more often than not) in a female form. Ariel embodies a harpy, a water-nymph, and Ceres - all female figures. The boy actor who played Ariel would also likely have been he who played the principal romantic heroines. ${ }^{21}$ There are obvious parallels between Prospero as director and Ariel as actor, and the audience would be primed to read the actor as female from other roles. There is nothing in the text to suggest Ariel has male sexual characteristics. There are, however, three instances in which Ariel is referentially gendered as male: "I come [...] Ariel and all his quality" (I.ii.189-93) Ariel declares, and two stage directions refer to how "He vanishes in thunder" (III.iii.82-3) and "claps his wings" (52-3). These stage directions were likely added by Ralph Crane, and thus we must acknowledge that this gendering is a post hoc assessment of Ariel; this is not to say Ariel has a pre-existing gender outside of the text, but Crane's interpretation is only that: an interpretation. Yet Ariel also self-genders: "Ariel and all his quality." Case closed, then: Ariel uses male pronouns and therefore identifies as male. But this is linguistically anachronistic. While gender neutral pronouns existed in this period, such usage was rare. Unless a figure is specifically designated female, both masculine and genderless figures would be referred to as "he" (Nevalainen 2006: 82). To conclude that Ariel's use of "his" grants Ariel a male gender is not only to ignore early modern pronoun usage, but to arbitrarily privilege such pronoun use over Ariel's physically female forms, as well as insisting that Ariel should conform to human understandings of gender rather than the very different sphere of fairy gender.

\footnotetext{
17 The debate as to the earliest date at which Ariel was played by a woman concerns the ambiguous language of Pepys' review of productions of the Dryden and Davenant adaptation of The Tempest. For an overview of the perspectives in this debate, see Dymkowski 2000: 35n70. ${ }^{18}$ Dymkowski (2000: 34-48) discusses the production history of Ariel's male, female, and nonbinary castings and provides some excellent photos.

${ }^{19}$ For Dymkowski (2000: 37), this is because "the Restoration version stamped Prospero [...] as a figure of patriarchal authority." This "necessitates a demure Miranda, a beast-like Caliban and an Ariel whose willing servility is seen as natural and inevitable: in other words, a gossamer female fairy."

${ }^{20}$ For discussions of when Ariel changes costume, see Jowett 1983 and Egan 1997.

${ }^{21}$ For Ariel being played by a boy-actor, see Sturgess 1987: 77.
} 
To complicate this further, Ariel is not merely androgynous but also childlike and mischievous. Though Ariel may be boylike, Fisher (2001: 155) has argued, "it would appear that boys were considered to be a different gender from men during the Renaissance" and that gender was constituted prosthetically (Fisher 2006), an idea that Preciado (2013: 227) and Halberstam (2005: 51) turn to in a twenty-first century context. Furthermore, for Stephen Orgel (1996: 109), the boy and the woman are economically analogous and "women and children [...] become the cultural metonyms for the working classes"; 22 of course, fairies are frequently servants as well, to humans or to other fairies, and the intersection of fairies, class, and gender is one that deserves more thorough treatment than can be granted here. Ariel is Prospero's "chick" (V.i.316), "bird" (IV.i.184), and "servant" (IV.i.33); Ariel is "quaint" (I.ii.317). Ariel is also petulant: Prospero's first interaction with Ariel in which he must remind Ariel of Sycorax's tyrannous rule is very much that of a teacher and his pupil, catechistically formatted, with Ariel not taught maturity but obedience (I.ii.244-300). To return to Fisher's point, if the child may function as a third gender, Ariel is far more readily collapsed into that third gender of servile, androgynous, shapechanging, dramaturgical childhood than that of a man. ${ }^{23}$ For Julie Crawford (2020), writing of John Milton's angels, "the most elevated state of embodiment is characterized by the absence of binary sex." Ariel, a being of fluidity and the elements who "ride[s] | On the curlèd clouds" (I.ii.190-1), is similarly privileged: a nonbinary fairy, with that indeterminacy tied defined not only by their elemental nature, but also their role as child.

This works both ways. If the nonbinary mode may be best aligned with supernature, it is not just fairies that are read as trans but also trans figures that are read as fairies. In Cymbeline, Belarius comes across the cross-dressed Innogen asleep in his cave and exclaims, "But that it eats our victuals I should think | Here were a fairy" (III.vi.40-1). He continues, "By Jupiter, an angel or if not, | An earthly paragon. Behold divineness | No elder than a boy" (43-5). Only able to construct gender from the sartorial fetish, Belarius would more easily see a fairy or an angel than a cross-dressed girl. Innogen's gender ambiguity renders her supernatural. And as Belarius moves back to the mundane he must emphasize her age, Innogen being "No elder than a boy!" Not simply "a boy" but "no elder than", suggesting that cusp of adolescence. Such liminal ages are the realm of fairies, specifically female adolescence, which is the point at which one is most likely to encounter them (Purkiss 2000: 86). Contrary to Ariel, rather than a fairy guise enabling gender instability, Innogen's transgender guise causes her to be read as a fairy. Thus when transness is encountered, it is foremost read in a supernatural mode.

Transness may be celebrated, as it is for Ariel and Innogen, but it may also provoke disgust. The titular fairy of Spenser's The Faerie Queene is Gloriana, a representation of Elizabeth I, and in this poem of doppelgangers one of Gloriana's many shadow-selves is the "false sorceresse" Duessa of Book I (XII.xxxiv.294). For Susan Stryker (2006: 9), "Transgender people who problematize the assumed correlation of a particular biological sex with a particular social gender are often considered to make false representations of an underlying material truth, through the willful distortion of surface appearance." Serano (2007: 36) specifies this argument for trans women, who are categorised as either "deceptive" or "pathetic", those in the former category "play[ing] the role of sexual predators." But in the Spenserian imagination, falsehood

\footnotetext{
22 On boys, homosexuality, and class, see also Bray 1982: 43-57, Saslow 1986: 155-60; Smith 1995: 167-9, Johnston 2005, 81-2.

${ }^{23}$ For other readings of Ariel's gender, see Nesler 2012 and Boğosyan 2013: 92-105.
} 
itself is represented through a perceived disconnect between biological sex and social gender. Duessa allegorizes falsehood (and Mary, Queen of Scots), appearing as a beautiful woman whose true nature is betrayed by the exposure of her misshapen genitals. ${ }^{24}$ Duessa seeks to mislead the knight Redcrosse from his quest and is described as "false Duessa seeming Lady faire," wherein her deceptive nature is defined by this semblance of fairness concealing foulness and sexual instability (IV.xiii.110).

To approach Duessa from trans historicity, we see how she is represented with the same tropes Serano identifies as the tactics of traditional sexism through by which trans women are commonly represented in modern media: hyperfeminization, the attribution of transition to sexual causes, and preoccupation with genitalia (Serano 2007: 14). Duessa is hyperfeminized with a focus on "frivolous" costuming, wearing "garments gilt" (V.26.232), "gorgeous gold" (233), "ornaments that richly were displaid" (VIII.xli.360), and comes "Adornd with gold and jewels shining cleare" (V.xxi.182). These external, prosthetic beauties contrast with the hideous somatic reality they conceal; similarly, "Her craftie head was altogether bald," prosthetically imitating femininity she cannot possess (VIII.xlvi.415). Serano's second point concerns the assertion that trans women "transition for primarily sexual reasons", and Duessa's beautiful, feminine façade is attired only to seduce knights away from the cis women they protect.

Redcrosse is tempted to abandon Una, the representation of chastity, to whom Duessa is the false alternative. Una is the platonic ideal of maidenhood against which Duessa is measured, and thus Duessa's beauty always serves as an artificial imitation of the feminine, normative, cis virgin. Duessa similarly misleads Fradubio, a knight now transformed into a tree. Fradubio compares Duessa's false beauty to that of his former love, "Th' one seeming such, the other such indeede," and ultimately abandons the true woman in favour of false Duessa (II.xxxvii.326). Thus Duessa's beauty is, like that of trans women, a false construct that imitates, competes with, and misleads men from appropriate heterosexuality.

Serano's final point concerns the sensationalization of sex reassignment surgery and the state of trans women's genitalia. Despite Duessa's ability to appear outwardly beautiful, she cannot alter her monstrous genitalia; when Fradubio spies her in a state of undress (an invasion of privacy that goes unaddressed), he finds "Her neather parts misshapen, monstruous" and "more foule and hideous, | Then womans shape man would beleeve to bee" (II.xli.361-4). Later, her intersexuality is associated with old age, as she is seen to possess both "dried dugs, like bladders lacking wind, | Hong downe, and filthy matter from them weld" (VIII.xlvii.420-1). When Duessa is finally defeated, her fate is one of violent exposure that confirms her false, malicious nature by the state of her genitals. She is forcefully stripped so that "their eyes might her behold" (VIII.xlix.411) and she becomes the subject of the public gaze as the "amazd" (xlix.433) onlookers look upon her "deformed" body (434), her "secret filth" (xlvi.414), her "misshaped parts" (412) and "her filthy feature open showne" (xlix.440) - a familiar trope for representations of trans women in modern media. Their paranoid epistemology is confirmed by exposure (Sedgwick 2002: 138-41), not merely justifying this violence but confirming its ethical imperative. As Stryker (2006: 10) writes, "Those who commit violence against transgender people routinely seek to excuse their own behavior by claiming they have been unjustly deceived by a mismatch between the other's

${ }^{24}$ There are other figures in The Faerie Queene of interest to trans studies, such as the crossdressed knight Britomart, the monstrous maternal beast Errour, and the Ovidian transformations to which multiple characters are subject. 
gender and genitals." 25 This is further articulated by Serano (2007: 37): "their 'secret' trans status is revealed in a dramatic moment of 'truth.' At this moment, the 'deceiver's appearance (her femaleness) is reduced to mere illusion, and her secret (her maleness) becomes the real identity." For Duessa, it is this same mismatch that justifies the violence perpetrated against her and which justifies the exposure of her "deformed" genitalia that reveals her as the representation of falsehood.

Duessa is not a real trans woman. She is a phobic fantasy that understands the hiding of sexed characteristics as undertaken purely to mislead men away from chastity, fidelity, and Protestantism. The same trope is employed in the contemporary Churchyard's Challenge (Churchyard: 1593), where the speaker encounters a pageant of beautiful fairy nobility. He beholds a "King, | a faire familiar spréet" with his "Lady like the Fairie Queene", accompanied by "Dames and Nymphes most chast" (176). And then on "a stately mighty mount" comes a lady "All clothed in white" who proclaims "A woman sure I am" (177) - but such self-identification is soon subverted. The beautiful fairy pageant is revealed to all be an illusion conjured by devils, and the speaker is faced instead with a parade of "fearefull bugges" who chastise him for forsaking God in favor of these trifling pleasures. What once appeared a parade of nobility are revealed to be shadows "With bellies big and swagging dugges, | more lothsome then a witch" (180) - coded as abject, aged women. For Judith Butler (2014), "we are all ethically bound to recognize another person's declared or enacted sense of sex and/or gender." Yet in these Protestant poetics the man is ethically bound to acknowledge and expose deception. The more dedicated we are to truth, faith, and chastity the easier we will be able to identify these deceptive, aged, transgender monsters for what they truly are: the embodiment of Catholic deception. ${ }^{26}$

A trans person may hide their gender identity for fear of violence, but modern "victims" of their secrecy claim it is done with malicious intent (Sharpe 2017). These early modern figures give no evidence of possessing any interior "gender identity" or dysphoria and only present as beautiful women in order to mislead men. Modern phobias of the transgender "trap" find obvious congruence with these anxieties; thus we can see how such phobic fantasies precede modern transmisogyny and derive from an older fear of, superficially, the supposedly deceptive nature of women but, more deeply, men's fear that their own sexual desires might betray them. Spirits "can either sex assume, or both," as John Milton writes, and this is as much a source of threat as wonder (I.424).

I turn finally to the story of Jocastus, "A fantastique sheapherd" and fairy fanatic, who attempts, alchemically, to transition into "Jocasta" so that she might marry King Oberon and become the

${ }^{25}$ See also the transgender panic defence; Woods, Sears, and Mallory 2016 offer a useful overview.

${ }^{26}$ Associations between Catholicism and gender disorder or sodomy were commonplace, with the Pope compared to the whore of Babylon to contrast with the virginal Elizabeth I. See for example the illustration of the Pope as the whore of Babylon in the 1545 edition of the Luther Bible and William Baldwin's Wonderfull Newes of the Death of Paule the III (1552), in which the Pope, in Hell, provides his clergy with a chalice of his own menstrual blood in place of the blood of Christ. See also representations of Pope Joan (Freeman 2006), particularly in relation to "the hermaphrodite hypothesis" (Rustici 2006: 85-105). 
Queen of fairyland. ${ }^{27}$ This is Randolph's Amyntas, first performed in 1630 - several decades later than these other works. Unlike The Tempest, this was performed by a company exclusively comprised of boy actors, the Children of the Revels, and it is not a coincidence that the only play to consider $\mathrm{MtF}$ transformation is performed entirely by boy actors. ${ }^{28}$ It is the story of two fools: Mopsus and Jocastus, an augur and a shepherd. Jocastus loves only the fairies and urges Mopsus to seek out a "Fairy Lady" for his bride (I.iii.5). Mopsus will have none of this. His idea of fairies is very Shakespearean, the kind of insectlike creatures who live among the undergrowth: he will not "looke a wife in nutshells" or "wooe a gnat" - he "must have flesh and blood" (9-11). Yet Jocastus is dedicated to pursuing a fairy bride - or husband, as eventually comes about. Jocastus is gulled into mistaking the mortal boy Dorylas for the fairy prince, who offers him the opportunity to transform into a woman and become his fairy bride. The plot occurs at Jocastus' expense: these scenes are comic and make of him a fool, but Dorylas' Oberon creates a ludic festival space in which such topsy-turvy impersonations of fairy princes also allow for transness to conceptually exist.

Jocastus loves the fairies, regardless of gender. When first confronted with what he believes to be Oberon and Queen Mab, Jocastus' primary interest is the Queen. He does not hesitate to kiss Queen Mab "With admirable courtship" and thinks "There will be of Iocastus brood in Fairy" (II.vi.6). Such extramarital affairs are common for Oberon and Titania of A Midsummer Night's Dream, and Jocastus himself has a fairylike hedonism. There is a fairy way of thinking and a mortal way of thinking - the fairy strategy conceptualizes such hedonistic affairs and gender transformation, and once Jocastus starts to think in that mode then the idea of transness can emerge. Though his first object of romantic affection is Mab, Jocastus' interests soon shift when Oberon/Dorylas seems to mistake him for a woman: as Dorylas tells Jocastus, "A beauteous Lady, bright and rare, | Queen Mab her selfe is not so faire" (V.vi.14-5). But Jocastus does not object to being read as a woman. Having first pursued Mab his interests now turn to Oberon in the sodomitical pun, "Does your grace take me for a woman then?" (16), expanded in Dorylas' comment that "Lady you will ruin mee" (24). A man would be ruined indeed, should he "take" (fuck) a man "for a woman." There is only one way for two men to have sex and avoid sodomy: one party must become a woman. Despite first claiming "I am no woman!" (25), Jocastus soon admits "I alwaies thought I was borne to be a Queene" (63). This is no contradiction: Jocastus initially understands that his genitals exclude him from female identification and asks if he will face a "geelding" (26), but Dorylas/Oberon promises a more fantastical means of gender transformation. Mystical gender transformations are a commonplace of classical mythology and medieval fairies were also capable of changing their genders, like Muldumarec of Marie de France's "Yonec", but such representations grow rare by the seventeenth century. By this period, gender transformations are the relics of an age when the woods and our own bodies were less known, were less stable.

Jocastus is free of the modern need to narrativize one's gender dysphoria in order to transition. ${ }^{29}$ There is no early modern etiology of transness; he undertakes transition almost on a whim. While much early autobiographical writing by trans women (and representations of the "pathetic

${ }^{27}$ I shift my pronouns from male to female to reflect Jocastus' understanding of transition.

${ }^{28}$ Munro (2018) presents an interesting examination of this play in relation to boy actors, gender, class, and disguise.

${ }^{29}$ See Hausman 2006 on the appropriation of autobiographical narratives of transition. 
transsexual") focus on the difficulty of appearing sufficiently feminine and attractive, Jocastus' pre-transition beauty is the source for Oberon/Dorylas to prompt her transition: "are you no woman then? | Can such bright beauty live with men?" (32-3). Jocastus immediately embraces the possibility of an alchemical change: "Cannot your Grace distill me to a woman?", hoping for the seventeenth century equivalent of HRT (35). The idea is lifted from Oberon's sexualityaltering potions in A Midsummer Night's Dream, but in Randolph's play it is gender, not sexuality, that can be transformed by a fairy plant. The herb here is moly, a false friend with the Latin mollis meaning softer, effeminate. Moly plays a similar role to the surgical intervention reified in early trans autobiographies by as the crucial transformative act that will create womanhood: ${ }^{30}$ in a precursor to comments such as Lili Elbe's on her surgery making her "a complete woman" (Elbe 1933: 178), Jocastus is urged to "tast this Moly but agree, | And thou shalt perfect woman bee" (38-9).

While Jocastus is mocked as much for her transgender identity, the transgender identity primarily serves to illustrate the foolishness of her fairy beliefs, rather than being something to mock on its own terms. If Jocastus agrees to marry Oberon, then "Queene Jocasta thou shalt bee" (43). Marriage and moly will provoke this transformation, Jocastus to Jocasta, with the kind of transgender linguistics we see in Ovid's Caenis/Caeneus. Once state power - Oberon - permits physical gender transition, Jocasta commits to the Real Life Experience and will "live full time in the preferred gender" (Meyer III 2001: 7). She refuses her servant's misgendering:

"Bro[mius]: Why master, are you mad? | Io. Your mistrisse sirrah" (53). The name is abbreviated "Io." so there can be no apparatic or paratextual authority outside the dialogue to assert that her name is "really" Jocastus. Jocasta is allowed, however briefly and however comically, to exist. Mopsus now has no difficulty calling her "Gracious sister" (and calls her "sister" again even once the trick has been revealed - once the comic space has allowed for trans identities to be conceptualized, they are easily absorbed; 62 and 79). The logic of gender transition is remarkably simple for one so committed to biopolitics, for "Our grace has said it, and it shall be so" (54). The state determines gender - here, Oberon; today, gender recognition panels. Jocasta is no longer concerned with questions of biological essentialism: while physical transition is necessary for Jocasta to fulfill her identity, that identity was created and conceptually permitted by Oberon's approval. An early example indeed of state-decreed transgender biopolitics, and an inversion of the modern state role in transition.

Jocasta is easily moved to love for Oberon; the two exchange only 30 lines before she is "up to th'eares in love" (41). It is Oberon's (pretended) fairy power, we assume, both magical and aristocratic, that moves Jocasta so quickly to romance. But though Oberon is "really" a disguised mortal boy and Jocasta is the butt of the joke, there is no disgust in this scene. Jocasta, fool though she might be in falling for the disguise, is mocked only for that foolishness; there is no repulsion for her sodomitical or transgender love. Once the fantastical possibility of gender transition has been created, Jocasta desires the same for her servant, Bromius, who would "make a very pretty waiting maid" (45). The motivation seems aesthetic rather than sexual or romantic. As Bromius is a servant, there would be little compromise to his social power (in Jocastus' eyes) should he become a woman. A pretty maid to wait upon a beautiful queen - such is Jocasta's transgender fairy dream.

${ }^{30}$ See Stone 1987 and Hausman 2006. 
It should not be overlooked that Jocasta is played by a boy actor, not an adult man. Lucy Munro (2018: 218), in analyzing the relationship between gender, age, and status in the play, argues:

Amyntas would lose far more of its impact without an all-boy cast, since the putative trans woman is an adult man. If Jocastus is played by a boy actor, he can at least potentially be transformed [...] In contrast, if Jocastus were to be played by an adult man the sequence would take on a different tone - perhaps more comic, perhaps more bleak in the context of a theatrical culture in which adult men rarely, if ever, performed female roles.

True - although we cannot really imagine the performance dynamics of such a play if Jocasta were not performed by a boy actor, because men were never transformed into women. ${ }^{31}$ A man may become a woman if he is played by a boy, and if a fairy is involved; otherwise, opportunities for $\mathrm{MtF}$ transformation remain beyond the reach of early modern drama.

But our Prince Oberon is not a fairy. Like Belarius, what we took for a fairy is only a boy - only this time, it really is a boy, not a boy-who-is-a-girl-who-is-a-boy. There can be no magical transformation and transsexuality is denied us. Yet ludic though the scene might be, Jocastus did become Jocasta, if only socially, for a little while. "I long to tast this Moly," she says, just before the jest is revealed, and it is this with which we are left (59). Had Shakespeare's Oberon been really here rather than Randolph's theatrical imitation of him, perhaps that transformation could have occurred.

Amyntas does not celebrate transgender identity. But it depicts a trans woman pursuing physical transition and doing so confidently and openly. She is not presented as disgusting, frightening, or dangerous; she is mocked only for her gullibility. How foolish of her to believe she could transition - and how foolish, too, to believe in fairies. This play was written in 1630, 35 years after A Midsummer Night's Dream in which fairies were met through the veil of "slumber[...]" (V.ii.55), and 20 years after The Tempest, in which Prospero drowned his magical book. We are a long way from the medieval fairy realities of Robin Good Fellow. Belief in fairies, and believe in trans people, is now only a joke. In Amyntas, the fairy and the trans woman thus occupy the same space: an impossible figure, not disgusting but ludicrous; silly, but not hateful. To believe in fairies is as foolish as to believe in being trans, Randolph suggests - yet that does not stop writers from constantly depicting transgender people, fairies, and transgender fairies.

\section{Conclusion}

Few actors are as critically acclaimed in the role of Twelfth Night's Olivia as Mark Rylance. "[I]t is difficult to imagine that Twelfth Night could be performed more effectively than it currently is at the Globe theatre, in an all-male production," Alex Needham (2012) writes. Critics construct a ritual of the appropriate way to enjoy the cross-dressed male body: "Rylance takes you through sex to some spiritual area beyond," writes Paul Taylor (2002), while Ben Brantley (2013) celebrates the enlightened state of not laughing at men in dresses and thus enjoying Shakespeare authentically: Rylance "show[s] he's as brilliant in trousers as he is in a dress [which] makes you

${ }^{31}$ Exceptions are merely transvestic characters like Falstaff in The Merry Wives of Windsor. See Chess 2016 for MtF transvestism beyond drama. 
think, 'This is how Shakespeare was meant to be done." Praise for Rylance is predicated upon the assumption that a man in a dress must be innately funny, and Rylance is hailed for exhibiting acting so powerful it makes you forget your transmisogyny - this is authentic Shakespeare.

This is nonsense, of course. An early modern audience would have reacted quizzically to 53year-old Rylance playing Olivia, as they would have expected a nine-to-fourteen-year-old boy in the role. Transmisogyny remains essential to the glorification of Shakespeare's cultural import. The early modern period could be phobic of trans femininity, but we must recognize when those phobias accord with modern transphobia and when they do not. Transphobia too has a history. Transgender figures were not always comic in early modern literature, and the fairy offered a means by which gender transformation or nonbinary identities could be conceptualized. Our modern fairies are more rooted in Shakespeare and his influences than any other text. The names of their medieval predecessors, such as Muldumarec of "Yonec" or other magical genderchangers like Bertilak of Sir Gawain and the Green Knight are little-known today in comparison to Oberon and his queen Titania. Early modern fairies remain some of the most recognizable otherworldly figures in western culture, and yet the gender instability that once characterized them is repeatedly and deliberately forgotten in order to affirm false transphobic histories like those in which Brantley participates. The fairies and their transness might have died out, but we must not overwrite their memories. These fairies' gender instability delights, threatens, and persists. Fairies might be such stuff that dreams are made of, but these texts do not always allow us to wake up. 


\section{Bibliography}

\section{Primary}

Allingham, William. 1908. “The Fairies.” In The Magic Casement: An Anthology of Fairy Poetry, edited by Alfred Noyes, 339-40. London: Chapman \& Hall.

Brantley, Ben. 2013. "Boys Will Be Boys (and Sometimes Girls).” The New York Times, November 10. https://www.nytimes.com/2013/11/11/theater/reviews/twelfth-night-and-richardiii-with-mark-rylance.html

Churchyard, Thomas. 1593. Churchyards Challenge. London.

Erasmus, Desiderius. 1904. 'De Pueris Instituendis', Concerning the Aim and Method of Education. Edited by William Harrison Woodward. Cambridge: Cambridge University Press.

France, Marie De. 1999. The Lais of Marie De France. London: Penguin.

Meyer III, Walter (chairperson). (1979) 2001. The Harry Benjamin International Gender Dysphoria Association's Standards Of Care For Gender Identity Disorders, Sixth Version. WPATH.

Milton, John. 2003. Paradise Lost. London: Penguin.

Needham, Alex. 2012. "Stephen Fry's Twelfth Night: This All-Male Affair Is No One-Man Show. The Guardian. 1 October 2012. https://www.theguardian.com/stage/2012/oct/01/stephenfry-twelfth-night-all-male

Randolph, Thomas. 1917 (1638). “Amyntas.” In The Poems and Amyntas of Thomas Randolph, edited by John Jay Parry. New Haven: Yale. 233-354.

Shakespeare, William. 2016. The New Oxford Shakespeare, edited by Gary Taylor, John Jowett, Terri Bourus, and Gabriel Egan. Oxford: Oxford University Press. Oxford Scholarly Editions Online.

Sir Gawain and the Green Knight. 1972. Edited by J. A. Burrow. London: Penguin.

Spenser, Edmund. 2003. The Faerie Queene. London: Penguin.

Taylor, Paul. 2002. "Mark Rylance: A Twelfth Night to Remember." The Independent. 2 February 2002. https://www.independent.co.uk/arts-entertainment/theatre-dance/features/markrylance-a-twelfth-night-to-remember-9257941.html 
Woods, Jordan Blair, Brad Sears, Christy Mallory. 2016. Model Legislation for Eliminating the Gay and Trans Panic Defenses. UCLA: The Williams Institute.

\section{$\underline{\text { Secondary }}$}

Aizura, Aren et al. 2014. "Introduction.” Transgender Studies Quarterly 1 no. 3: 308-19.

Boğosyan, Natali. 2013. Postfeminist Discourse in Shakespeare's The Tempest and Warner's Indigo: Ambivalence, Liminality and Plurality. Newcastle: Cambridge Scholars Publishing.

Boon, Jessica A. 2018. "At the Limits of (Trans) Gender: Jesus, Mary, and the Angels in the Visionary Sermons of Juana de la Cruz (1481-1534)." Journal of Medieval and Early Modern Studies 48, no. 2: 261-300.

Bray, Alan. 1982. Homosexuality in Renaissance England. London: Gay Men’s Press.

Bushnell, Rebecca W. 1996. A Culture of Teaching: Early Modern Humanism in Theory and Practice. New York: Cornell University Press.

Butler, Judith. 2014. "Gender Performance: The TransAdvocate interviews Judith Butler." Interview by Cristan Williams. Transadvocate May 12014.

https://www.transadvocate.com/gender-performance-the-transadvocate-interviews-judithbutler_n_13652.htm

Button, Anne. 2001. “Ariel.” In The Oxford Companion to Shakespeare, edited by Michael Dobson and Stanley Wells. Oxford: Oxford University Press. Oxford Reference Online.

Bychowski, M. W. 2016. "Unconfessing Transgender: Dysphoric Youths and the Medicalization of Madness in John Gower's 'Tale of Iphis and Ianthe'." Accessus: A Journal of Premodern Literature and New Media, 3.

Bychowski, M. W. and Dorothy Kim. 2019. "Visions of Medieval Trans Feminism: An Introduction." Medieval Feminist Forum: A Journal of Gender and Sexuality 55 no. 1: 6-41.

Bychowski, M. W. et al. 2018. “"Trans*historicities': A Roundtable Discussion.” Transgender Studies Quarterly 5 no. 4: 658-685.

Chess, Simone. 2020. “Queer Residue: Boy Actors' Adult Careers.” Journal of Early Modern Cultural Studies: Early Modern Trans Studies. Forthcoming.

---. 2016. Male-to-Female Crossdressing in Early Modern English Literature: Gender, Performance, and Queer Relations. London and New York: Routledge. 
Chess, Simone, Colby Gordon and Will Fisher. 2020. "Introduction.” Journal of Early Modern Cultural Studies: Early Modern Trans Studies. Forthcoming.

Clifton, Zac. 2018. "Becoming Trans: Transgender Identity In The Middle Ages.” The Establishment. March 7. https://theestablishment.co/becoming-trans-transgender-identity-in-themiddle-ages-223e01b5c0dc/index.html

Crawford, Julia. 2020. "Transubstantial Bodies in Paradise Lost and Order and Disorder." Journal of Early Modern Cultural Studies: Early Modern Trans Studies. Forthcoming.

DeVun, Leah and Zeb Tortorici. 2018. “Trans, Time, and History.” Transgender Studies Quarterly 5, no.4: 518-539.

Dinshaw, Carolyn. 1999. Getting Medieval: Sexualities and Communities, Pre- and Postmodern. Duke: Duke University Press.

Dinshaw, Carolyn et al. 2007. “Theorizing Queer Temporalities.” GLQ 13: 177-195.

Dymkowski, Christine. 2000. "Introduction.” In The Tempest. Edited by Christine Dymkowski, 1-93. Cambridge: Cambridge University Press.

Edelman, Lee. 2004. No Future: Queer Theory and the Death Drive. Durham: Duke University Press.

Egan, Gabriel. 1997. "Ariel's Costume in the Original Staging of the Tempest." Theatre Notebook 51: 62-72.

Enterline, Lynn. 2012. Shakespeare's Schoolroom: Rhetoric, Discipline, Emotion. Philadelphia: University of Pennsylvania Press.

Felski, Rita. 1996. "Fin de siècle, Fin de sexe: Transsexuality, Postmodernism, and the Death of History." New Literary History 27 no. 2: 337-349.

Fisher, Will. 2006. Materializing Gender in Early Modern English Literature and Culture. Cambridge: Cambridge University Press.

---. 2001. "The Renaissance Beard: Masculinity in Early Modern England.” Renaissance Quarterly 54, no. 1: 155-187.

Freccero, Carla. 2006. Queer/Early/Modern. Duke: Duke University Press.

Friedlander, Ari. 2016. "Desiring History and Historicizing Desire." Journal for Early Modern Cultural Studies 16 no. 2: 1-20. 
Gamble, Joseph. 2020. "Toward a Trans Philology." Journal of Early Modern Cultural Studies: Early Modern Trans Studies. Forthcoming.

Gill-Peterson, Julian. 2018. Histories of the Transgender Child. Minneapolis: University of Minnesota Pres.

Goldberg, Jonathan. 1992. Sodometries: Renaissance Texts, Modern Sexualities. Stanford: Stanford University Press.

Goldmark, Matthew. "Reading Habits: Catalina de Erauso and the Subjects of Early Modern Spanish Gender and Sexuality”, Colonial Latin American Review, 24.2 (2015), 215-235.

Green, Richard Firth. 2016. Elf Queens and Holy Friars: Fairy Beliefs and the Medieval Church. Philadelphia: University of Pennsylvania Press.

Gutt, Blake. 2018. “Transgender Genealogy in Tristan de Nanteuil.” Exemplaria 30, no. 2: 129146.

Gutt, Blake and Alicia Spencer Hall, eds. Under contract. Trans and Genderqueer Subjects in Medieval Hagiography. Amsterdam: Amsterdam University Press.

Halberstam, Jack. 2005. In a Queer Time and Place: Transgender Bodies, Subcultural Lives. New York: New York University Press.

Halpern, Richard. 1991. The Poetics of Primitive Accumulation: English Renaissance Culture and the Genealogy of Capital. London: Cornell University Press.

Harf-Lancner, Laurence. 1991. Les Fées au Moyen Âge: Morgane et Mélusine; la Naissance des Fees. Paris: Paris Champion.

Horbury, Ezra. 2019. Prodigality in Early Modern Drama. Woodbridge: Boydell and Brewer.

Horden, Peregrine. 1999. Disease, Dragons and Saints: The Management of Epidemics in the Dark Ages. Cambridge: Cambridge University Press.

Howard, Jean. 1988. "Crossdressing, The Theatre, and Gender Struggle in Early Modern England." Shakespeare Quarterly 39, no. 4: 418-440.

Johnston, Mark Albert. 2017. "Shakespeare's Twelfth Night and the Fertile Infertility of Eroticized Early Modern Boys.” Modern Philology 114 no. 3, 573-600.

---. 2011. Beard Fetish in Early Modern England: Sex, Gender, and Registers of Value. London and New York: Routledge. 
Jones, Ann Rosalind and Stallybrass, Peter. Renaissance Clothing and the Materials of Memory (Cambridge: Cambridge University Press, 2000).

Jowett, John. 1983. "New Created Creatures: Ralph Crane and the Stage Directions in The Tempest." Shakespeare Survey 36, 107-20.

Karras, Ruth Mazo and Tom Linkinen. 2016. "John/Eleanor Rykener Revisited." Founding Feminisms in Medieval Studies: Essays in Honor of E. Jane Burns, eds. Laine. E. Doggett and Daniel E. O’Sullivan. Woodbridge: Boydell \& Brewer. 111-22.

Kemp, Sawyer K. 2019. "'In That Dimension Grossly Clad”: Transgender Rhetoric, Representation, and Shakespeare.” Shakespeare Studies 47: 120-13

Klosowska, Anna, Masha Raskolnikov, and Greta LaFleur. 2021. Trans Historical: Gender Plurality Before the Modern. Ithaca: Cornell.

Levine, Laura. 1994. Men in Women's Clothing: Anti-theatricality and Effeminization, 15791642. Cambridge: Cambridge University Press.

Mann, Jennifer. 2006. "How to Look at a Hermaphrodite in Early Modern England." Studies in English Literature 1500-1900 46, 67-91.

Masten, Jeffrey. 2016. Queer Philologies: Sex, Language, and Affect in Shakespeare's Time. Philadelphia: University of Pennsylvania.

Menon, Madhavi. 2016. Unhistorical Shakespeare: Queer Theory in Shakespearean Literature and Film. New York: Springer.

Mills, Robert. 2018. "Visibly Trans?: Picturing Saint Eugenia in Medieval Art." Transgender Studies Quarterly 5 no. 4: 540-564.

Munro, Lucy. 2018. "Queering Gender, Age, and Status in Early Modern Children's Drama." In Queering Childhood in Early Modern English Drama and Culture, edited by Jennifer Higginbotham and Mark Albert Johnston, 215-37. Cham, Switzerland: Palgrave Macmillan. ---. 2009. "Coriolanus and the Little Eyases: The Boyhood of Shakespeare's Hero." Shakespeare and Childhood. eds. Kate Chedgzoy, Susanne Greenhalgh, and Robert Shaughnessy. Cambridge: Cambridge University Press. 80-95.

Nesler, Miranda Garno. 2012. "Gender and Otherness in 'The Tempest." Performing Humanity: Humans and Animals in the Modern World, December 10.

https://performinghumanity.wordpress.com/2012/12/10/gender-and-otherness-in-the-tempest/ 
Nevalainen, Terttu. 2006. An Introduction to Early Modern English. Oxford: Oxford University Press.

Orgel, Stephen. 1996. Impersonations: The Performance of Gender in Shakespeare's England. Cambridge: Cambridge University Press.

Pfeffer, Jess. 2013. "Circulating Desire, Shifting Bodies: The Transsexual Eroticism of Middleton and Dekker's The Roaring Girl." Desire, Performance, and Classification: Critical Perspectives on the Erotic. Oxford: Inter-Disciplinary Press. 71-79.

Purkiss, Diane. 2000. Troublesome Things: A History of Fairies and Fairy Stories. London: Penguin.

Rose, Emily. 2016. "Keeping the Trans in Translation: Queering Early Modern Transgender Memoirs." TSQ: Transgender Studies Quarterly 3, 485-505.

Rose, Jacqueline. 1984. The Case of Peter Pan or the Impossibility of Children's Fiction. New York: Springer.

Rubright, Marjorie. 2020. "Transgender Capacity in Thomas Dekker and Thomas Middleton's The Roaring Girl (1611)." Journal of Early Modern Cultural Studies: Early Modern Trans Studies. Forthcoming.

Sedgwick, Eve Kosofsky. 1991. "How To Bring Your Kids Up Gay.” Social Text 29: 18-27.

Sedinger, Tracey. 1997. "'If Sight and Shape be True': The Epistemology of Crossdressing on the London Stage." Shakespeare Quarterly 48, no. 1: 63-79.

Sharpe, Alex. 2017. "The Ethicality of the Demand for (Trans)parency in Sexual Relations." Australian Feminist Law Journal 43 no. 2: 161-183.

Smith, Bruce R. 1995. Homosexual Desire in Shakespeare's England: A Cultural Poetics. Chicago: University of Chicago Press.

Spade, Dean. 2006. "Mutilating Gender." The Transgender Studies Reader, eds. Susan Stryker and Stephen Whittle. New York: Routledge. 315-32.

Sparey, Victoria. 2015. "Performing Puberty: Fertile Complexions in Shakespeare's Plays." Shakespeare Bulletin 33 no. 3, 441-467.

Stallybrass, Jones. 1992. "Transvestism and the 'Body Beneath': Speculating on the Boy Actor." Erotic Politics: Desire on the Renaissance Stage. Ed. Susan Zimmerman. London: Routledge. 64-83. 
Stavreva, Kirilka. 2018. "Ariel's Groans, or, Performing Protean Gender on the Bulgarian PostCommunist Stage.” Shakespeare Survey 71: 103-112.

Stewart, Alan. 1997. Close Readers: Humanism and Sodomy in Early Modern England. Princeton: Princeton University Press.

Stockton, Kathryn Bond. 2009. The Queer Child, or Growing Sideways in the Twentieth Century. Durham: Duke University Press.

Stryker, Susan. 2006. “(De)Subjugated Knowledges: An Introduction to Transgender Studies.” The Transgender Studies Reader, eds. Susan Stryker and Stephen Whittle. New York: Routledge. 1-17.

Sturgess, Keith. 1987. Jacobean Private Theatre. London: Routledge \& Kegan Paul.

Traub, Valerie. 2002. The Renaissance of Lesbianism in Early Modern England. Cambridge: Cambridge University Press.

Varnado, Christine. 2016. "Getting Used, and Liking It: Erotic Instrumentality in Philaster." Renaissance Drama 44 no. 1:25-52.

Wagner, Geraldine. 2011. "Dismembering Desire: Cross(dress)ing the Boundaries of Gender and Genre in The Life and Death of Mary Frith, Commonly Called Moll Cutpurse." English Studies 92, no. 4: 375-99.

Whittington, Karl. 2018. "Medieval Intersex in Theory, Practice, and Representation." Postmedieval 9, no. 2: 231-247. 